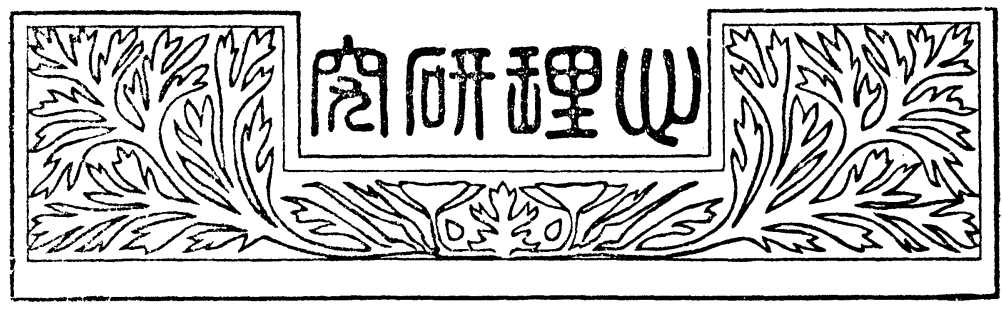

\title{
$\checkmark$ 删昰第卷五第
}

记古馀の管惯とめ研

淽峳华著り驗心此究實

足め問韭心的々のの喛

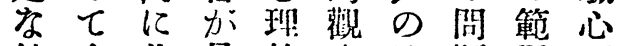

結多此最的察は題園理

論占听初研法: 分に學

亿。問て究疲歐於加

到け題あは探營洲 $\tau$ 敎

達れにる一用测てて亩

しど關。八守定非市の

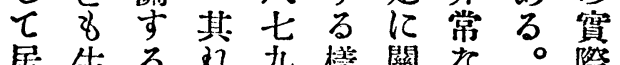

居生る礼九核關怙。際

理著に年にす議事問

的述引になる諭の題

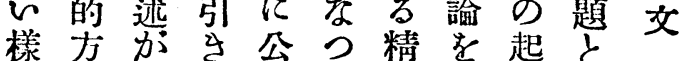

厂面非縜にて密起马密學

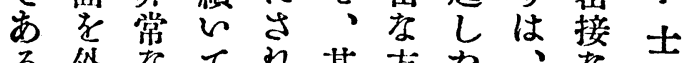

方外夌てれ其方九梦

。江數年れの法時生る

蓋しに名露解加徒關

乙て上多國決技其の你

田 豆声

疲

勞

の

徵

候

の)

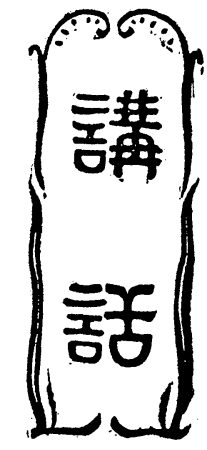

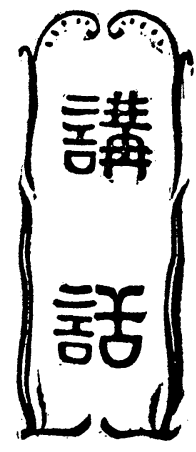

問はうくの加公负

題精九の心二つ解据有

神。研理步九決過つ

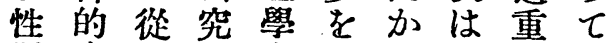

質疲分分者進号甚の來

上勞て出

研に其てコれ市困題の宽

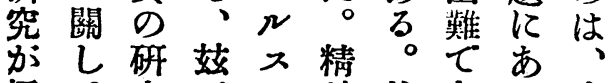

中

極儿究管 $\neq$ 神然古方疲一

めは方干1的万方勞

て未法有氏疲に初の 


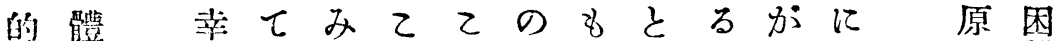

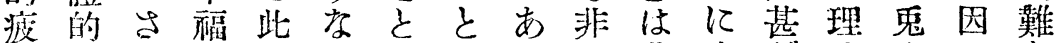

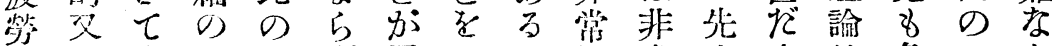

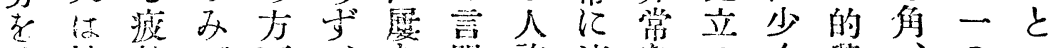

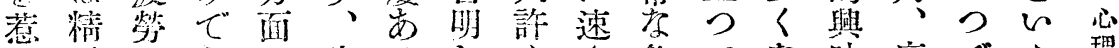

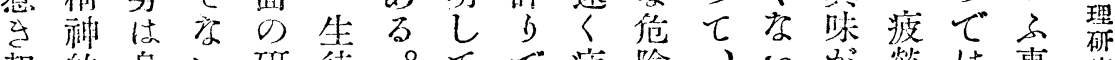

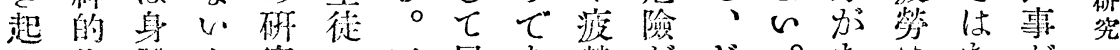

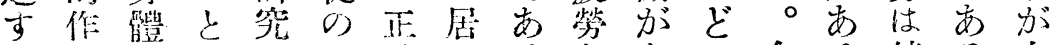

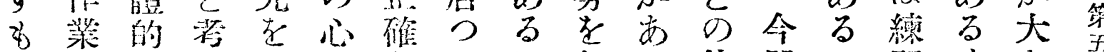

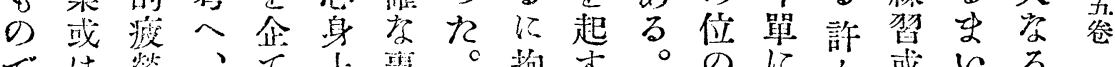
ては繁、て

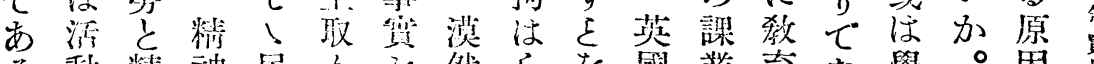

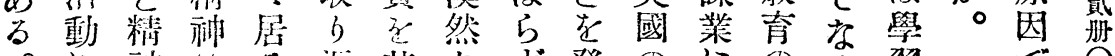

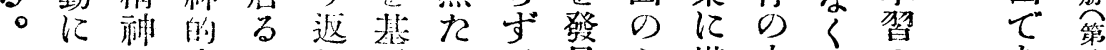

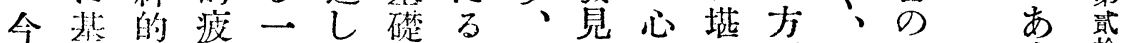

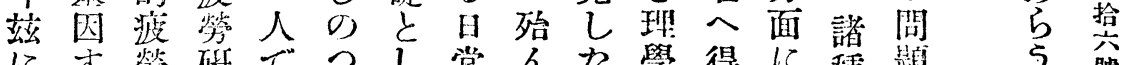

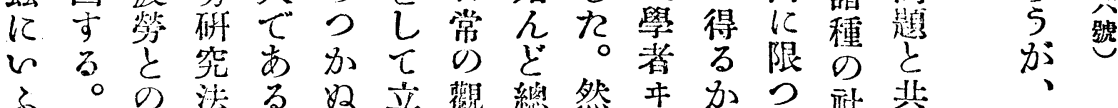

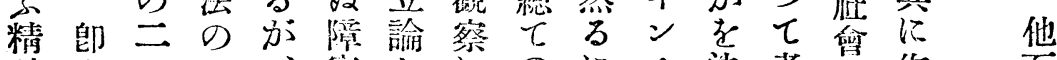
神ちつ一、菩しにのに千洼考閣作面

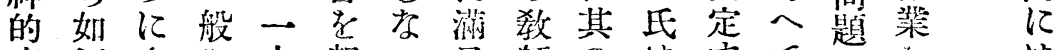

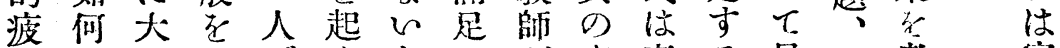

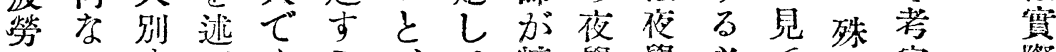

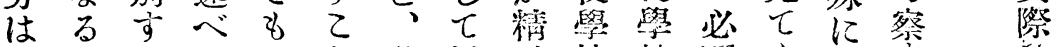

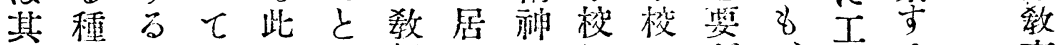

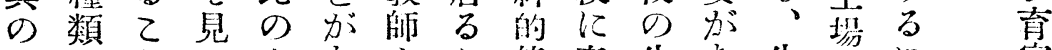

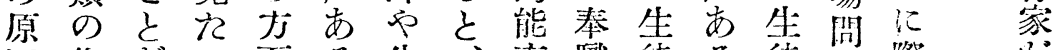

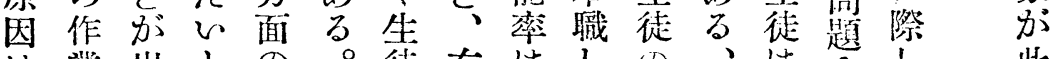

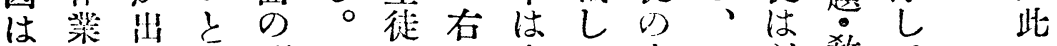

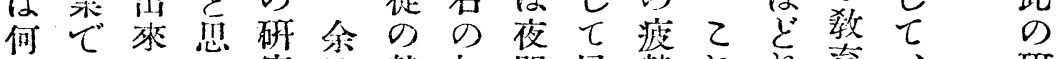

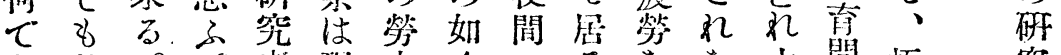

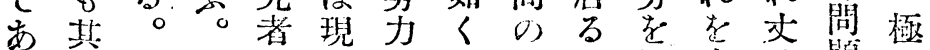

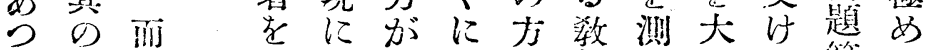

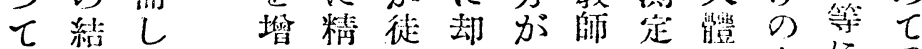

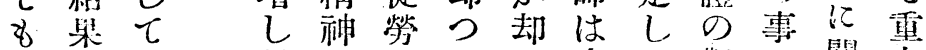

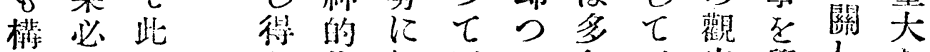

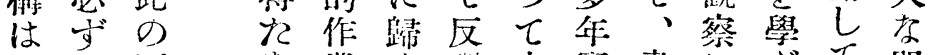

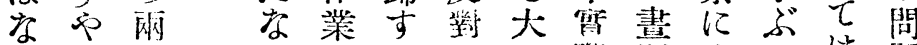
几身者 らのてので際間止べは題

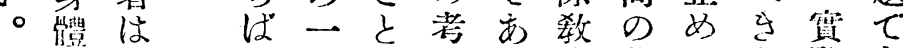
唯的何余要吕へる亩學て 分祭あ 或更礼 万 䊎 8

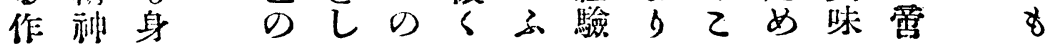
- 素多をと校㛝を的る 己と心惇的經よく定興。事 突保 助 力 告

與 宛 分 $D$ わ 


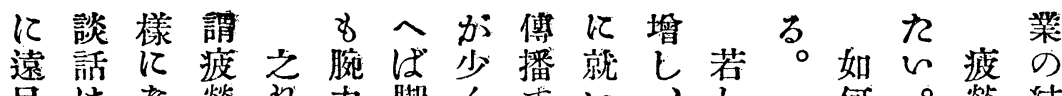

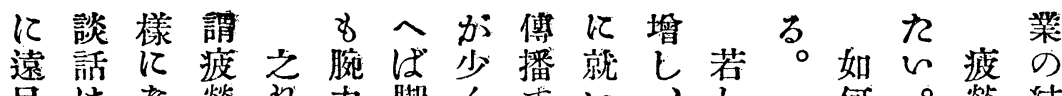
足はな勞犯力脚く寸い、し何。管結

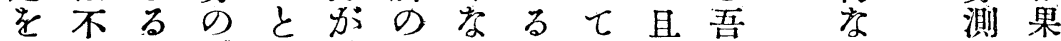

虑試活。感同減作る。はつ令

勞 み澉各情時少策。最寧澡加

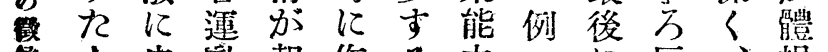

人皮動起作る力八に反、操

○想各る 筹

の的步のの

。孞ば作對又步

奋常江行で初

中

吉 經 䭾 $\overrightarrow{\text { 層 }}$

驗湆層年

すヤの同つ

ると努時れ

處分力に快

控多其活

とく要の学

信な娄作感

守り、る。業情

。逐之嫌な

又にれ堅く

外全にし 尔

界人伴、る

の沈 5 逐。

刺 默 $て$ 漸

戟に思は次

に了考如に

對る作何疲

七。用な机

七此少るた

威等 緩 作 と

鶹吕慢瑟感

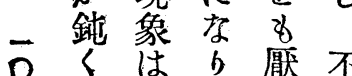

表女變的快

名金华等

- 它柺体覺

之步息之

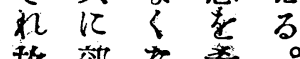

減步業說脉行

る゙行艿が搏㗶

許段減当速山

占退。广

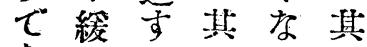

なかる。る の

（飞。外之他

$\checkmark$ 郎體之筋

他短与溫务肉

の反初出認の

琎且昇作

つ江つら策

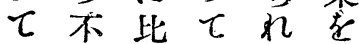

居磪し乘る長

なに七る 、

心挂。优續

四了事先子け

肢。はづ非る

而緩㗢 常

筋し慢加に民

力 $て$ し努に

加特字て方は

少につ居し、

緊七るた啳

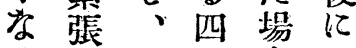

るし同肢合は

- たしにに呼

る 定と

作

業

8

身

の

方 $\tau$

法 精

次的

兩號 方

方㵽

面述に

にベ現

酷るは

似证

ब文了

徵に疲

候勞

๘ $\tau$

現、乙

殅 疲炎

の加市

で 身る

当两

方

占面

今 如

先何

己泟

例現

は は

即西時發は吸

ち肢間汗除は

身犯

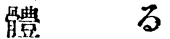

的名

旅㐫乙外非

作 の

敌郊学希。

行今口遂例常

にの任にでに

業概

\pm 例事全、度

保外了及所

つでの身 2 數

七言量に狆笔

に院

取

它

見見 
又は復てす薄單時てラ動にすむ は此守疲る な一に居ンの作努乙以之頂 皮のるれ。る筋は号々結栔力と步々に

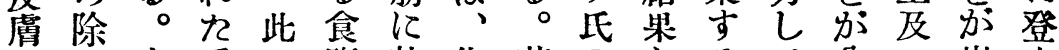
及去之手の鹽就作落のとるて分乙出豆

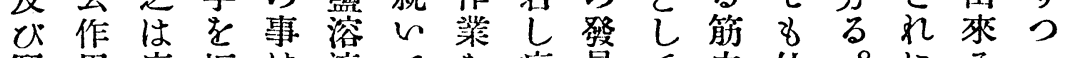
腎用疲振は留てを疲見て因任。にる。的 臟加焱う 前 $\widehat{0}$ 發し管し筋に事逐類。れ

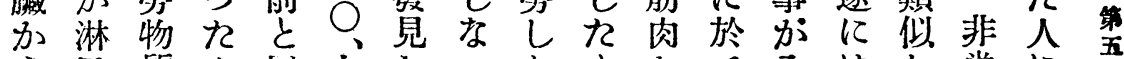

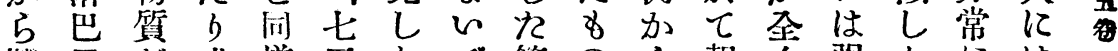

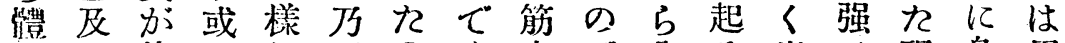
外吅使はに至の的肉て分る 出的现身周 に動用旅動二で直に、泌生來て象能壹

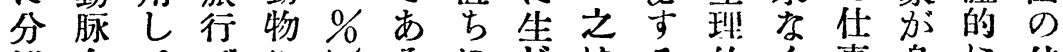
泌血てでに元にじはる的く事身に佳

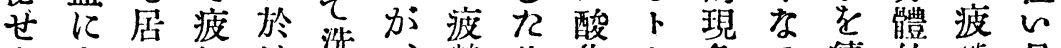
らよるれけ流、勞此化 $\neq$ 象る續的勞景

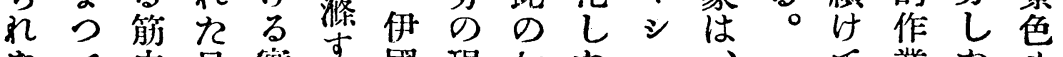

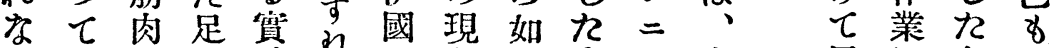

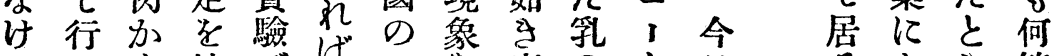

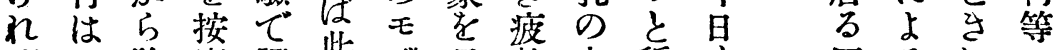

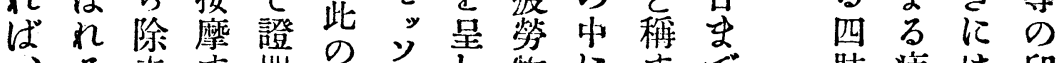
る去守明物、し物に卞で肢波は印 循。せるせ物は、質あるすの䃕其像

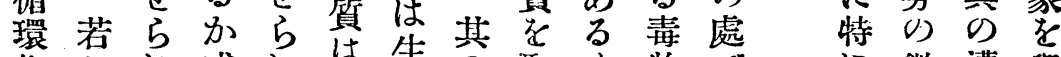
作しれ或狆取生公取各物元行遭與

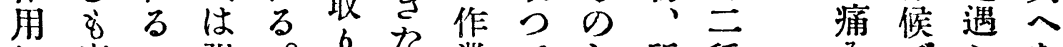

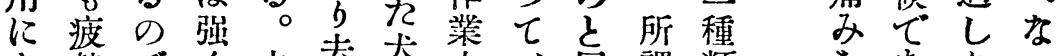

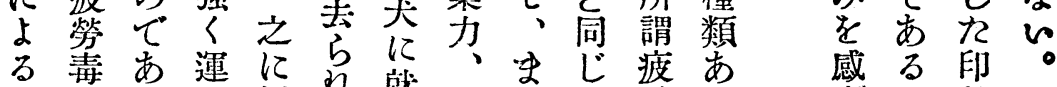

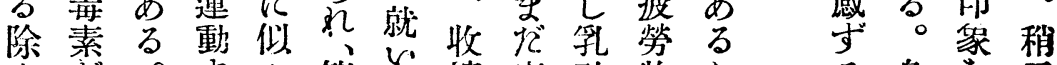

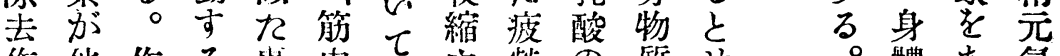

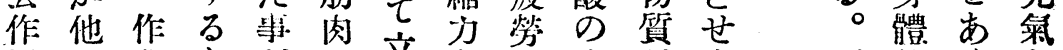

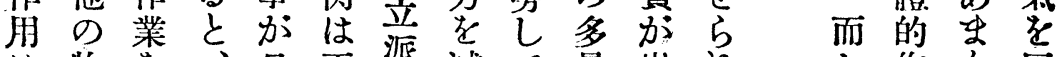

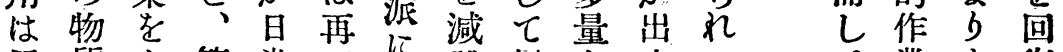

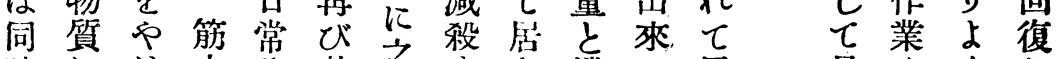

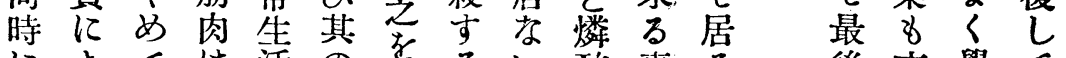
によては活の證るい酸事る 後亦覺て 漸う休暫に作證。筋加で。に精之初

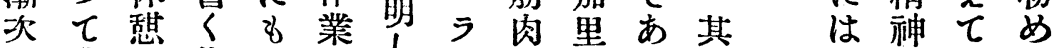
全消守作あ能九沉酸る。第幾的居て

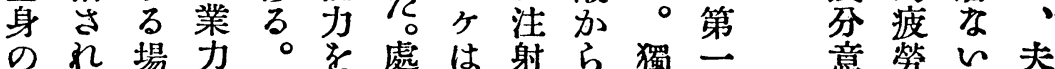

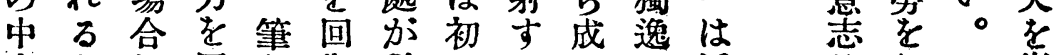
毒加に回記復稀めるつの活的起樂 


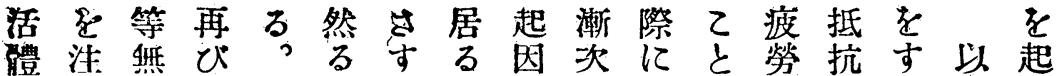

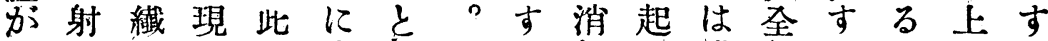

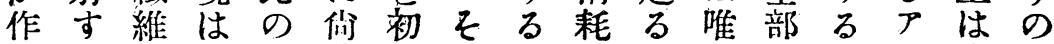

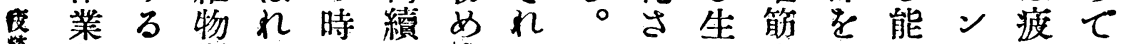
然を質るはけ疲は生れ理肉取力テ 勞 あ す蛙の。疲七焱次理る的疲 b孛1物る

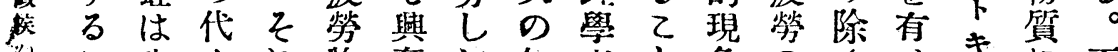

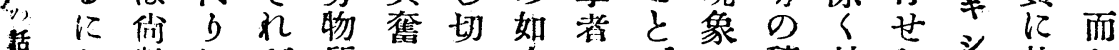

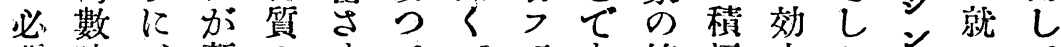

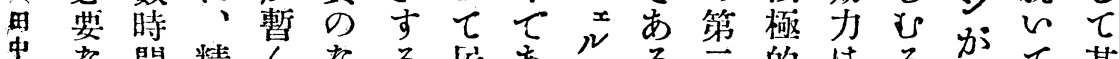

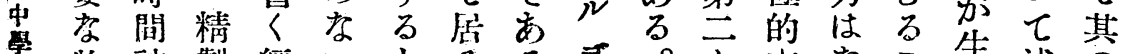
志物 被製 經 6 と る る

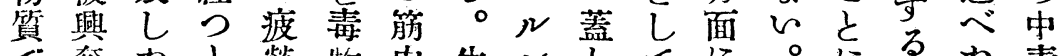
で奮てと勞物肉生ンしてい毒

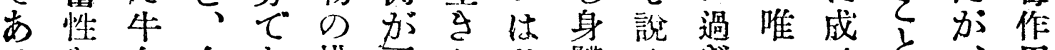

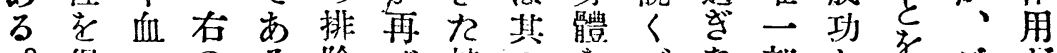
。保へのる除び蛙のをべな部し学ヷ肪 而有此溶。は被の有棐云分九發人如

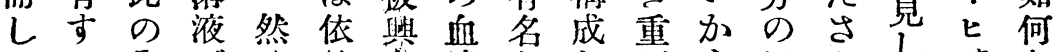

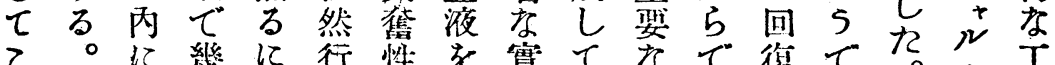

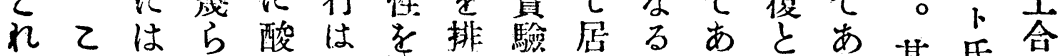

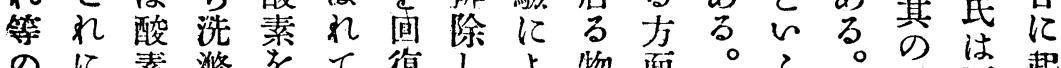

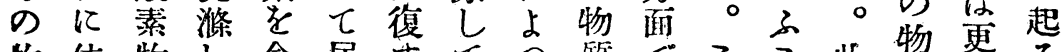

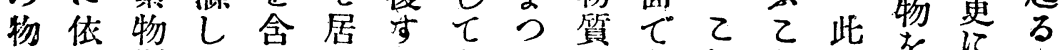

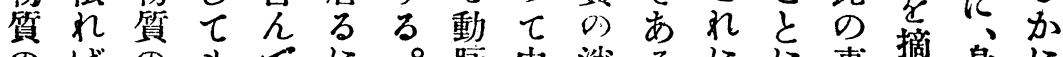
のばの \&でに。脉中消るにに事挏身に

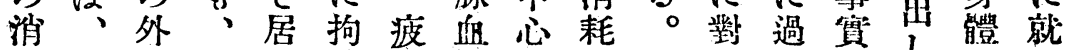
費酸に少るは勞管神肪そしざはし 內い 加素炭し食ら物中經其れ视假、にて

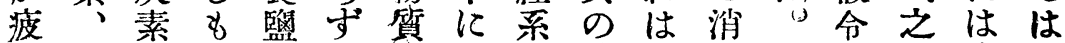
勞炭文興溶終肪八統同作檴其確を疲茲

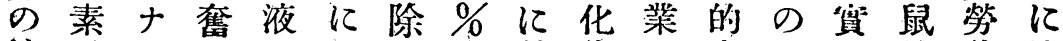
消、下它ては至少付作に方理てに物は 極ナリな蛙再せ純い用よ面由而あ注貿說

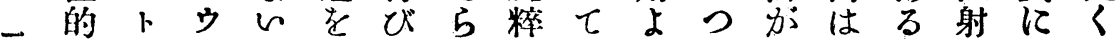
$\overrightarrow{0}$ 方 五面 ウをに子興る食確的脂る營してて要

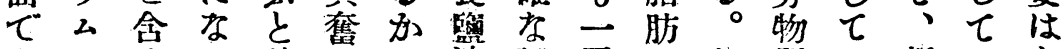
あはんる被性ら溶證層と師質子暫区な

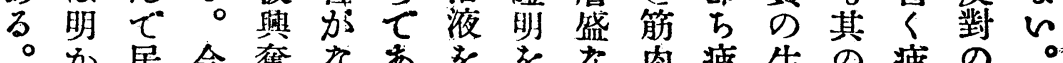

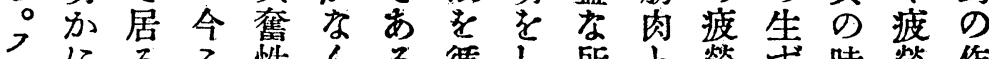
○にる乙性くる循し所々勞守時勞作

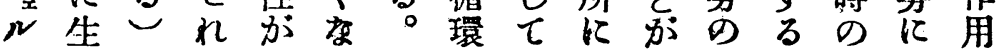




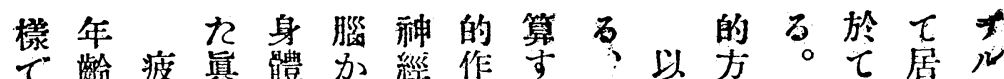
はの管理のら系柴れ即上面之はる ま差のて他血統には古はとれ!。は 的鼻徵市の液によ誤任身疲故物筋此 。男候亏部の特亏方事䣓勞に晢肉の

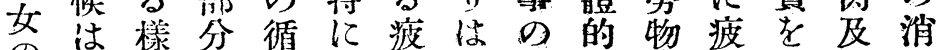
品概ての環疲勞多結作質勞攝 ひ極 別略あ物に管のく果業をに取神的

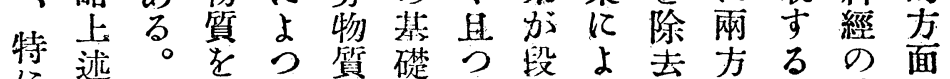

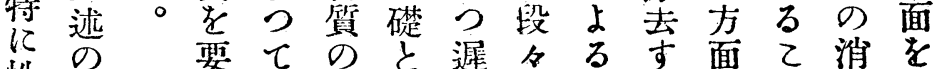

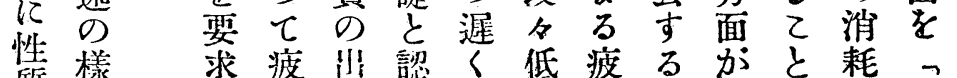

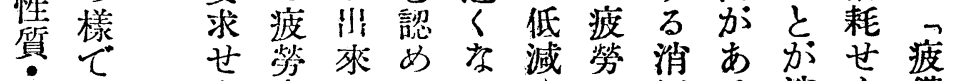

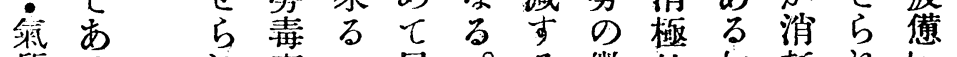
質る和素之居。る徽的如耗㣗

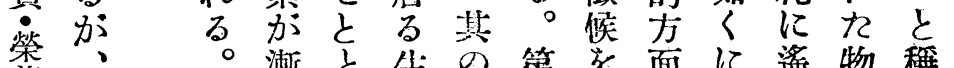
養泟之生の第它面に遥物稱 勿次組理他一述と策加筫 L 諭傳絨的身に元養に老、

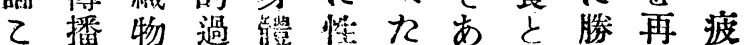

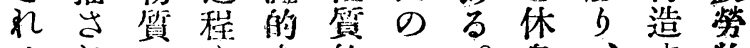
は视の方的で。息、古物 假、破身面に无石劦

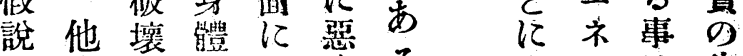

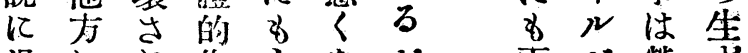

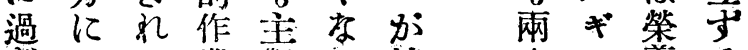

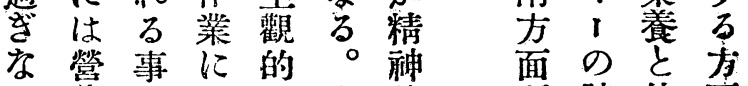

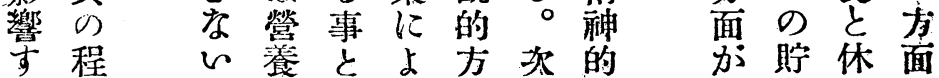
る度出に考る面に作萜息の ○を、よへ疲には業 又異今うて管的分に 同に旦てょの洦量よ 一专尘充心場し的方 のる元分。合的疲

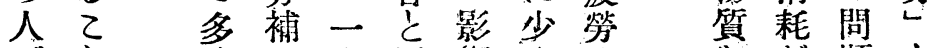
て

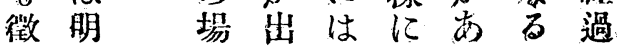
候分來㗢、方。名 はて应交大。例同

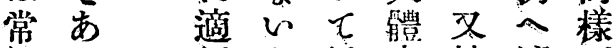

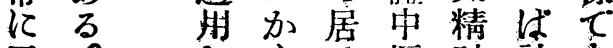

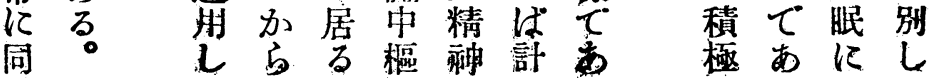

補來睡 כ 充、眠 疲 物 消 の笋 ぜはあら しれるの む万。 る 睡澏 